\title{
Nowhere in the Middle Ages. Karma Lochrie. The Middle Ages Series. Philadelphia: University of Pennsylvania Press, 2016. 270 pp. $\$ 65$.
}

Christopher Kendrick

Loyola University Chicago, ckendri@luc.edu

Follow this and additional works at: https://ecommons.luc.edu/english_facpubs

Part of the English Language and Literature Commons

\section{Recommended Citation}

Kendrick, Christopher. Nowhere in the Middle Ages. Karma Lochrie. The Middle Ages Series. Philadelphia: University of Pennsylvania Press, 2016. 270 pp. \$65.. Renaissance Quarterly, 70, 3: 1222-1224, 2017. Retrieved from Loyola eCommons, English: Faculty Publications and Other Works, http://dx.doi.org/ $10.1086 / 695269$

This Book Review is brought to you for free and open access by the Faculty Publications and Other Works by Department at Loyola eCommons. It has been accepted for inclusion in English: Faculty Publications and Other Works by an authorized administrator of Loyola eCommons. For more information, please contact ecommons@luc.edu.

\section{cc) (†) $\ominus$}

This work is licensed under a Creative Commons Attribution-Noncommercial-No Derivative Works 3.0 License. (C) The Renaissance Society of America 2017 
author to refresh existing approaches on the subject dealt with. Furthermore, the reader can find at the end of every note many suggestions for other entries in the dictionary that can usefully complete the first search made. Most of these notes are short but a few ones are longer, especially when they concern important concepts such as "love," "poetic genres," or "women."

Despite the great number of contributors and the considerable work of Rouget, I sometimes noticed little discrepancies, especially on the little-known festive poetry of Ronsard. If Jean Braybook writes that Ronsard's Bergerie, composed in 1564, "must never have been performed (according to the opinion of Paul Laumonier)" (76), Margaret McGowan considers that this masquerade has been performed during the Carnival of Fontainebleau, at the beginning of the royal "tour de France" of Charles IX, in the place called "la Vacherie" (249). I regret that this masquerade is qualified as "a kind of masquerade-pastorale or eclogue-ballet” (76), without any precision. Indeed, the term ballet was not used by Ronsard before 1581 ("Cartel pour le combat à cheval, en forme de balet"), and it is really questionable to speak about ballets while the poet himself chooses to insert his Bergerie in a collection entitled Elégies, Mascarades et Bergerie (1565). These critical remarks, however, do not in any way question the value of those two brilliant contributions or the interest of the whole book, which is both scholarly and accessible. On many subjects, this dictionary can be used as a real companion to Pierre de Ronsard: it is complete and definitely well grounded in the historical and critical materials.

Adeline Lionetto, Université Paris-Sorbonne

Nowhere in the Middle Ages. Karma Lochrie.

The Middle Ages Series. Philadelphia: University of Pennsylvania Press, 2016. 270 pp. $\$ 65$.

Histories of the utopian genre tend either to begin with Thomas More's Utopia (1516), or start with Thales and Plato and the classical city, and then turn in short order to More. Both ways effectively accept More's implicit claim as to his work's novelty, its break with medieval-clerical language and tradition: the pun in its title, depending on knowledge of Greek, pretends to divide humanist from Scholastic readers, letting only the former in on the joke concerning Utopia's fictive status. Karma Lochrie allows that Utopia establishes a new literary genre. But she is concerned to show that the three centuries before More were rich in utopian traditions both discursive and generic, and to argue that More was working within and upon them when he composed Utopia. For Lochrie, More's antimedievalism goes only language deep; otherwise, he should be understood as developing medieval society's complex discursive legacy concerning other worlds. 
She devotes chapters to four otherworldly works, each representing a discursive tradition: Macrobius's Commentary on the Dream of Scipio, with its Stoic cosmologism; the fable of the Land of Cokaygne, associated with Carnivalesque materialism and skepticism; Mandeville's Travels, animated by a cosmopolitan ethical minimalism; and William Langland's Piers Plowman, shadowing the ethical and organizing power of craftwork. To establish that these works are part of an alternative-world tradition broader than the strictly utopian, she discusses one or two textual descendants in the latter pages of each chapter. Though she does conclude with a chapter on Utopia itself, her overall emphasis is on the manysidedness of medieval utopianism.

The most original chapters are on Cokaygne and Mandeville. Lochrie argues for the superior cognitive value of the mid-thirteenth-century French poem Le fabliau de Cokagne over the more discussed Middle English Land of Cokaygne (ca. 1330). Le fabliau, some memorable pages show, is a sharper, more questioning, indeed more seriously utopian work than has been recognized. The Middle English poem, extant in a manuscript evidently produced by an Anglo-Norman community in Ireland, retains the utopian questioning, but complicates it to somewhat doubtful ends by combining it with a satire on monasticism (the island of Cokaygne becomes an abbey). Lochrie's assessment of the effect of the satiric component might be debated; but her reading is based on a philological knowledge and analysis of the manuscript and poem far superior to what one encounters in the better-known accounts of the history of utopia.

Lochrie makes a similar case for the philosophical depth of Mandeville's book of wonderful sights and lands. Mandeville's description of Cathayan, Greek Orthodox, and Saracen cultures—religiously minimalist and undogmatic, all of them, though in distinct ways — successfully relativizes and calls into question Western Christian missionary dogmatism. This argument carries conviction, as does Lochrie's contention that Utopia itself learned from these parts of Mandeville's book (though her claim that Utopia is backwardly provincial seems to me to overlook Hythlodaeus's stress on how the Utopians are quick to imitate and take over what they find of value in encounters with other cultures).

Finally, Lochrie's chapter on Piers Plowman as a work about its own failures of vision, of negative utopianism, offers a patient and penetrating reading of this complex and difficult poem. Although the dream vision was subsequently to figure often in utopian generic tradition (witness Morris), Langland's importance to More is not primarily formal, but rather ideological. The poem's staging of the attempted education of Will (of Will as desire or power of resolve, and as Will Langland) into a communal Will, and the eventual passage of Saint Peter's mediating power to Piers Plowman, with the substitution of a gift of crafts for that of tongues - this peasant re-visioning of the church, Lochrie argues, Langland's discovery of a work-based communal Christianity, was, in its persistence as an ideology, of major assistance to Utopia's critique of private property, and to its extension and quasi-secularization of monastic values. This 
seems obviously right; and though, as Lochrie notes, it has been suggested before, I know of no one who has actually worked out the case as Lochrie has. Lochrie's book explains, then, far better than those influential critics who hold that More's achievement in Utopia is to offer a radical critique of radical humanist political discourse, how More felt himself able to imitate The Republic to such devastating effect, exposing it as prepolitical, as taking traditional class society for granted.

Christopher Kendrick, Loyola University Chicago

\section{Second Death: Theatricalities of the Soul in Shakespeare's Drama.}

\section{Donovan Sherman.}

Edinburgh Critical Studies in Shakespeare and Philosophy. Edinburgh: Edinburgh University Press, 2016. $x+214$ pp. $£ 70$.

Donovan Sherman's Second Death begins with the question "what is a soul?" and explores how and where we might detect the elusive entity onstage in Shakespeare's plays. The study is concerned mainly with the soul as "lived practice" rather than with the departed soul (8), though Lear's unseen and imagined ghost opens the monograph, and Hamlet's ghost appears in the conclusion. Although the theater might seem an unlikely place to look for the soul's presence in the living (to look for more than portrayals of ghosts, that is), Sherman points out that the theater "mediates itself in relation to something beyond its capacities - an implied world, character, or quality that the audience fabricates through the perception of arranged concrete cues," a process that "resonates with the means by which the soul maintained its own necessary distance from complete definition" (8).

Sherman traces the soul from Cordelia's vanished breath to Hermione's breathing statue, producing fresh readings of Shakespeare, while using Shakespeare, in turn, to illuminate philosophical concepts of the soul. The first chapter proposes that the soul is theatrical but not mimetic, expressive but beyond representation. Sherman draws on Ludwig Wittgenstein, Stanley Cavell, and Jean-Luc Nancy, among others, to develop the idea of the expression, as opposed to the representation, of the soul, which becomes a key concept unifying the chapters. Chapter 1 delineates major strands of thinking on the soul, from Plato through to Catholic and Protestant theories, with an aim of highlighting, in the following chapters, traces of these discourses in theater and society. Chapters 2, 3, and 4 argue that certain Shakespearean characters become souls within the logic of their plays, namely Shylock, Coriolanus, and Leontes, but also Jessica and Mamillius, among others. As soul, these characters become isolated or expelled from the "representational fabric" of theater, within which the soul "starts to look like just the opposite: a villain, a pariah, or a madman" (10). Each chapter deals with the paradox of the soul as detectable only through its absence, as beyond percep- 